\title{
METODE PENETAPAN WAKTU SALAT MENURUT DEWAN SYARIAH WAHDAH ISLAMIYAH
}

\author{
Ronny Mahmuddin \\ Sekolah Tinggi Ilmu Islam dan Bahasa Arab (STIBA) Makassar \\ Email: ronnymahmuddin@gmail.com
}

\author{
Abdul Munawir \\ Sekolah Tinggi Ilmu Islam dan Bahasa Arab (STIBA) Makassar \\ Email: dulnawir@stiba.ac.id
}

\section{Muslimin}

Sekolah Tinggi Ilmu Islam dan Bahasa Arab (STIBA) Makassar

Email: muslimin@gmail.com

Keywords:
method, prayer, wahdah,
astronomy, rukyat

astronomy, rukyat

This study aimed to identify and recognize the correct method in determining shari prayer times according to Sharia Board of Wahdah Islamiyah. The issues in this study were; First, Islamic jurisprudence and the position of the sun being the main point of reference according to the Sharia in determining the initial time for prayer; Second, the law of employing astronomy in determining the initial time for prayer; Third, the correct method in determining shari prayer times according to Sharia Board of Wahdah Islamiyah. The type used was descriptive qualitative (non-statistical) research, which focused on the study of scripts and texts, employing a normative approach (shari) with field studies in the form of interviews with related figures. The results of the study show that; first, to recognize the Islamic jurisprudence and the position of the sun as the main point of reference in determining the initial time for prayer must be understood based on the propositions in the Koran and sunnah through the interpretation of the scholars who were well-known for their credibility. Second, in determining the prayer time schedule, the main method used is the method of rukyat with the help of astronomy as a means and device, but not as a primary point of reference. In addition, the process of preparing the prayer schedule is necessarily conducted through discussions by experts of Islamic jurisprudence and astronomy, both those affiliated with Wahdah Islamiyah and experts from outside Wahdah Islamiyah who are willing to provide recommendations and suggestions.

\section{Kata kunci :}

metode, salat, falak, rukyat.

\section{ABSTRAK}

Penelitian ini bertujuan untuk mengetahui dan memahami
metode yang tepat dalam menentukan waktu salat yang syar" $\bar{l}$
menurut Dewan Syariah Wahdah Islamiyah. Permasalahan yang
diangkat dalam penelitian ini yaitu; pertama, bagaimana fikih
dan kedudukan matahari sebagai patokan utama menurut syariat
dalam penentuan awal waktu salat; kedua, bagaimana hukum
penggunaan ilmu hisab/falak dalam penentuan awal waktu salat;


ketiga, bagaimana metode yang tepat dalam menentukan awal waktu salat sesuai syariat menurut Dewan Syariah Wahdah Islamiyah. Jenis yang digunakan adalah penelitian deskriptif kualitatif (non-statistik), yang terfokus pada studi naskah dan teks, serta menggunakan metode pendekatan normatif (syar'i) dengan studi lapangan berupa wawancara tokoh terkait. Hasil penelitian menemukan bahwa; pertama, untuk mengetahui fikih dan kedudukan matahari sebagai patokan utama dalam penetapan awal waktu salat, harus dipahami berdasarkan dalil-dalil dalam al-Qur'an dan sunah melalui interpretasi para ulama yang diakui kredibilitas keilmuannya. Kedua, dalam menetapkan jadwal waktu salat, metode utama yang digunakan adalah metode rukyat dengan bantuan ilmu falak sebagai sarana dan alat bantu, namun bukan sebagai patokan dasar. Di samping itu, dalam proses penyusunan jadwal salat tersebut diharuskan melewati serangkaian diskusi dan musyawarah oleh para ahli fikih dan astronomi, baik yang telah berafiliasi dengan Wahdah Islamiyah ataupun pakar dari luar Wahdah Islamiyah yang siap memberikan masukan dan arahan.

\section{PENDAHULUAN}

Manusia sebagai makhluk yang mulia mempunyai tugas utama yaitu melakukan ibadah kepada Allah Ta'ala, Rabb semesta alam, sebagaimana Allah dalam firman-Nya:

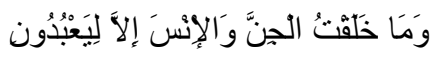

Terjemahnya: "Aku tidak menciptakan jin dan manusia melainkan agar mereka beribadah kepada-Ku." (Qs. al-Żāriat/51: 56) ${ }^{1}$

Dalam perspektif ajaran Islam, ibadah merupakan ajaran dasar yang diperintahkan kepada seluruh mukalaf (orang yang telah dewasa yang wajib menjalankan hukum-hukum Islam) ${ }^{2}$ sebagai bentuk pengabdian diri seorang hamba kepada Allah Sang Pencipta. Hal ini merupakan suatu keharusan untuk dilakukan dengan sikap ikhlas dan semata-mata mengharap balasan dari Allah Ta'ala, sehingga idealnya terhadap kewajiban ini adalah dilakukan dengan bekal ilmu yang memadai, pengetahuan yang benar dan pemahaman yang proporsional. Baik dari segi dasar pensyariatannya (landasan normatif), maupun dari sisi pengamalan atau penerapannya. Syarat diterimanya ibadah ada dua, yakni tidak menyembah kecuali hanya kepada Allah (ikhlas), dan tidak menyembah kecuali

${ }^{1}$ Departemen Agama Republik Indonesia, al Kaffah ,Al-Quran dan Terjemah, Jakarta: Sukses Publishing,2012. h.523.

${ }^{2}$ Dendy Sugono, Kamus Bahasa Indonesia, (t. Cet; Jakarta: Pusat Bahasa Departemen Pendidikan Naional, 2008), h.978. 
dengan apa yang disyariatkannya (mutaba'ah). ${ }^{3}$ Sebagaimana dalam firman Allah Ta'ala:

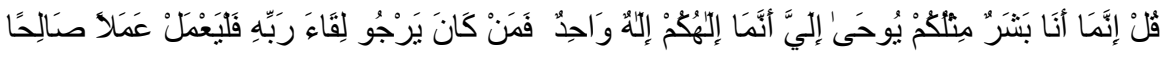

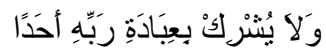

Terjemahnya: "Katakanlah (Muhammad), "Sesungguhnya Aku ini hanya seorang manusia seperti kamu, yang telah menerima wahyu, Bahwa sesungguhnya Tuhan kamu adalah Tuhan yang Maha Esa." Maka barangsiapa mengharap pertemuan dengan Tuhannya, maka hendaklah dia mengerjakan kebajikan dan janganlah ia mempersekutukan dengan sesuatu pun dalam beribadah kepada Tuhannya." (Qs. al- Kahfi/18 : 110)

Demikianlah semisal salat yang merupakan rukun Islam, identitas utama seorang muslim. Bukti keagungannya ketika Allah Ta'ala menetapkan syaratsyarat khusus terkait keabsahannya yang tidak terdapat pada ibadah-ibadah yang lain. Syarat wajib salat ada empat yaitu; suci, menutup aurat, menghadap kiblat dan tiba waktunya. Khusus masalah waktu salat, al-Qur'an menegaskan dalam surah al-Nisā. Allah Ta'ala berfirman:

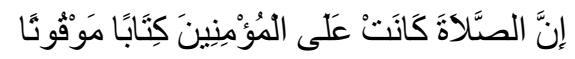

Terjemahnya: "Sungguh salat itu adalah kewajiban yang ditentukan waktunya atas orang-orang yang beriman." (Q.S. al-Nisa'/4: 103)

Siapa saja yang ingin mengerjakan salat, maka ia harus yakin akan masuknya waktu salat. Para ahli fikih berpendapat jika seseorang ragu akan masuknya waktu salat, maka ia tidak boleh salat hingga ia yakin. ${ }^{6}$ Sebuah kesimpulan kemudian lahir bahwa terdapat jadwal salat yang tersebar di masyarakat pada kenyataannya tidak sesuai dengan fakta tanda-tanda atau metode yang syar'̄̄ dalam penetapan awal waktu salat sehingga menuai keraguan di tengah masyarakat. Keseragaman penetapan waktu salat adalah merupakan salah satu ikhtiar dalam mempersatukan umat Islam. Yunta, A. H. D., mengatakan bahwa salah satu tujuan utama syariat Islam dan visi terdepan diutusnya para Nabi dan

${ }^{3}$ Syeikh Muhammad bin Șalih al-Uṡaimīn, Syarah Śalaśah Al-Ușul, (t. Cet ; t.t.p. :Dar al Kutub al-Ilmiyah, 1424 H), h.23.

${ }^{4}$ Departemen Agama Republik Indonesia, Al Kaffah ,Al-Quran dan Terjemah, Jakarta: Sukses Publishing,2012. h.304.

${ }^{5}$ Departemen Agama Republik Indonesia, Al Kaffah ,Al-Quran dan Terjemah, Jakarta: Sukses Publishing,2012. h.95.

${ }^{6}$ Ibnu Qudāmah Al-Maqdisī, al-Mughnī (t. Cet.; t.t.p.: al-Maktabah al-Syāmilah, t.th) [CDROM], al-Qāhirah: Maktabah al-Qāhirah. 1986, juz. I, h. 280. 
Rasul oleh Allah adalah untuk merealisasikan persatuan umat dan jemaah kaum muslimin. ${ }^{7}$ Adapun salah satu ormas di Indonesia yang memiliki misi menyatukan kaum muslimin adalah Wahdah Islamiyah.

Wahdah Islamiyah adalah sebuah organisasi Islam di Indonesia dipimpin oleh Dr. KH. Muhammad Zaitun Rasmin, Lc., M.A. Organisasi ini pertama kali didirikan pada tanggal 18 Juni 1988 M dengan nama Yayasan Fathul Muin (YFM) dan berubah menjadi Yayasan Wahdah Islamiyah (YWI) yang berarti "persatuan Islam." Manhaj organisasi ini mendasarkan pemahaman dan amaliahnya pada Al-Qur'an dan Sunah sesuai pemahaman Ahlu al-Sunnah Wa al-Jamā'ah atau salaf saleh yang bergerak di bidang dakwah, pendidikan, sosial, muslimah, informasi, kesehatan, dan lingkungan hidup. Adapun ihwal penyebaran informasi penetapan jadwal salat adalah merupakan bagian dari upaya dakwah kepada masyarakat luas.

Di antara alasan peneliti memilih Ormas Wahdah Islamiyah sebagai sumber penelitian adalah bahwa Wahdah Islamiyah adalah salah satu ormas besar yang memang patut dipertimbangkan. Khususnya di wilayah Sulawesi Selatan, melihat respon positif masyarakat yang begitu baik dan perkembangannya yang terhitung cepat sebagai salah satu ormas berbasis agama Islam. Sekalipun Ormas Wahdah Islamiyah tergolong ormas yang masih muda belia, namun, ia telah memiliki jutaan kader dan simpatisan di seluruh tanah air, bahkan di luar negeri seperti di Saudi Arabiyah dan Malaysia. Yang demikian itu lantaran Wahdah Islamiyah memiliki kelebihan dari sisi kualitas sumber daya manusia, kaderkadernya yang kompeten dan kompetitif yang tidak dimiliki oleh ormas-ormas lainnya, khususnya perhatian mereka terhadap ilmu syar'̄ beserta implementasinya dalam kehidupan sehari-hari, dengan ikatan persaudaraan yang begitu erat, ataupun loyalitas mereka dalam berdakwah melalui Ormas Wahdah Islamiyah yang merupakan pengejewantahan dakwah nabi itu sendiri.

Berdasarkan paparan di atas, maka dirumuskan masalah sebagai fokus pengkajian dalam penelitian ini yaitu:

1. Bagaimana fikih dan kedudukan matahari di awal waktu salat berdasarkan tanda-tanda yang ditetapkan syariat?

2. Bagamanakah hukum menggunakan ilmu hisab/falak dalam penentuan awal waktu salat?.

${ }^{7}$ Yunta, A. H. D. (2019). Tinjauan Hukum Pelaksanaan Salat Id di Beberapa Masjid yang Berdekatan Dalam Satu Wilayah. NUKHBATUL'ULUM: Jurnal Bidang Kajian Islam, 5(1), 5463.

${ }^{8}$ https://id.wikipedia.org/wiki/Wahdah_Islamiyah (di akses pada tanggal 10/02/2020) 
3. Bagaimana metode penetapan waktu salat menurut Dewan Syariah Wahdah Islamiyah?.

Dengan demikian, maka tujuan dari penelitian ini yaitu sebagai berikut:

1. Untuk mendeskripsikan bagaimana menentukan waktu salat berdasarkan tanda-tanda yang ditetapkan syariat.

2. Untuk mengetahui hukum menggunakan ilmu hisab/falak dalam menentukan awal waktu salat.

3. Untuk mengetahui metode yang tepat dalam menentukan awal waktu salat menurut syariat dan khususnya meninjau pendapat Dewan Syariah Wahdah Islamiyah mengenal hal tersebut.

Jenis penelitian yang digunakan dalam penelitian ini adalah kualitatif deskriptif dengan prosedur pengumpulan data melalui wawancara informan kunci (key informant) dan manuskrip (kearsipan), sehingga analisis deskriptif sangat ditekankan pada penyimpulan hasil penelitian. Novira, N., \& Ahmad, A., mengimbuhkan bahwa penelitian kualitatif deskriptif juga bertujuan untuk memahami fenomena atau peristiwa yang dilakukan oleh subjek penelitian sehingga menghasilkan data deskripsi berupa informasi lisan dari beberapa orang yang dianggap lebih tahu, dan perilaku serta objek yang diamati. ${ }^{9}$ Untuk mencapai maksud yang diharapkan dalam penelitian ini, maka metode pendekatan yang digunakan adalah pendekatan normatif (syar' $\bar{\imath})$. Pendekatan normatif yang dimaksud penulis adalah metode ilmiah untuk menghasilkan sebuah pandangan yang berlandaskan pada pemahaman dan penafsiran pada ajaran Islam (al-Qur'an dan hadis) yang digunakan sebagai landasan penentuan awal waktu salat.

\section{PEMBAHASAN}

\section{Fikih Penetapan Waktu Salat}

Secara normatif berdasarkan dalil-dalil al-Qur'an dan teks hadis Nabi Muhammad saw., waktu-waktu salat dalam fikih diperinci sebagai berikut: ${ }^{10}$

1. Awal waktu zuhur, dalam al-Qur'an, surah al-isra' ayat 78 disebutkan Liduluki al-syams, sejak tergelincirnya matahari. Atau dalam ilmu falak

${ }^{9}$ Novira, N., \& Ahmad, A. (2019). Tinjauan Akidah Islam Terhadap Adat Mappalili di Balla Lompoa Kelurahan Baju Bodoa Kecamatan Maros Baru Kabupaten Maros Sulawesi Selatan. NUKHBATUL'ULUM: Jurnal Bidang Kajian Islam, 5(1), 15-25.

${ }^{10}$ Muhammad Hadi Bashori, Pengantar Ilmu Falak, (Cet.1; Jakarta Timur: Pustaka kautsar, 2015), h. 147-150. 
disebut kulminasi, yaitu puncak tertinggi, titik tinggi yang dicapai suatu benda langit dalam peredaran (semunya) mengelilingi bumi (seperti matahari mencapai titik kulminasi pukul 12.00), ${ }^{11}$ maka waktu zuhur adalah dimulai ketika tergelincirnya matahari dari tengah meridiam langit (istawa') ke arah barat ditandai dengan terbentuknya bayangan suatu benda sesaat setelah posisi matahari di tengah langit, atau bertambah panjangnya bayangan suatu benda, sesaat setelah posisi matahari di tengah langit dan waktu zuhur berakhir ketika masuk waktu asar. Yang dimaksud tengah langit bukanlah zenith (Titik di angkasa yang berada persis di atas pengamat), ${ }^{12}$ akan tetapi tengah-tengah langit diukur dari ufuk timur dan barat.

Saat masuk waktu zawal (ketika matahari melewati garis langit yang menghubungkan utara dan selatan). ${ }^{13}$ Ihwal zawal, Nabi saw. pernah bersabda dalam hadis riwayat Muslim yang artinya: “...Waktu salat zuhur adalah ketika tergelincir matahari (menuju arah terbenamnya) hingga bayangan seseorang sebagaimana tingginya selama belum masuk waktu asar..." ${ }^{14}$ Kemudian ada tiga kemungkinan arah bayangan benda yang berdiri tegak. Pertama, arah bayangan berada di utara benda tersebut, yaitu ketika matahari melintasi zawal, posisinya berada di belahan langit selatan, azimuth $180^{\circ}$ (sudut antara satu titik dengan arah utara dari seorang pengamat atau disebut dengan sudut kompas). ${ }^{15}$ Kedua, arah bayangan berada di selatan benda tersebut, yaitu ketika matahari melintasi zawal, posisinya berada di belahan langit utara, azimuth $0^{\circ}$ atau $360^{\circ}$. Ketiga, tidak ada bayangan sama sekali, yaitu ketika matahari melintasi zawal, posisinya tepat berada di atas zenith yakni posisi matahari berada pada sudut $90^{\circ}$ diukur dari ufuk.

Pada saat kondisi pertama dan kedua, bayangan suatu benda sudah ada pada saat zawal, sehingga masuknya waktu zuhur adalah bertambah panjangnya bayangan suatu benda tersebut sesaat setelah zawal. Kondisi ketiga, pada saat zawal, suatu benda yang berdiri tegak tidak menimbulkan bayangan sedikitpun, sehingga masuknya waktu zuhur adalah ketika terbentuknya/munculnya bayangan suatu benda sesaat setelah istiwa'/zawal. Panjang bayangan saat

${ }^{11}$ Dendy Sugono, Kamus Bahasa Indonesia, (t. Cet; Jakarta: Pusat Bahasa Departemen Pendidikan Naional, 2008), h.773.

${ }^{12}$ Muhammad Hadi Bashori, Pengantar Ilmu Falak, (Cet.1; Jakarta Timur: Pustaka kautsar, 2015), h.74.

${ }^{13}$ Muhammad Hadi Bashori, Pengantar Ilmu Falak, (Cet.1; Jakarta Timur: Pustaka kautsar, 2015), h.148.

${ }^{14}$ Muslim bin Hajjaj bin Muslim al-Naisabūr, Shahih Muslim, (t.Cet.; Beirut : Ihya al-Turaś, t.th) Juz 1, hadis 427. h.612.

${ }^{15}$ Muhammad Hadi Bashori, Pengantar Ilmu Falak, (Cet.1; Jakarta Timur: Pustaka kautsar, 2015), h.75. 
datangnya waktu zuhur ini akan berpengaruh pula pada penentuan waktu asar.

2. Masuk awal waktu asar, dalam hadis yang diriwayatkan Ahmad, al-Nasa'i dan Tirmidzi dari Jabir ra. disebutkan waktu asar adalah ketika panjang bayangan suatu benda sama panjangnya dengan benda tersebut. Ihwal waktu asar, Nabi saw. pernah bersabda dalam hadis riwayat Muslim yang artinya: “...Waktu salat zuhur adalah ketika tergelincir matahari (menuju arah terbenamnya) hingga bayangan seseorang sebagaimana tingginya selama belum masuk waktu ashar dan waktu asar masih tetap ada selama matahari belum menguning..."16 Dalam surah Qāf ayat 39 disebutkan juga akhir waktu asar adalah qabla gurūb, yaitu sebelum matahari terbenam. Dalam fikih, waktu asar dimulai ketika panjang bayangan suatu benda, sama dengan panjang benda tersebut dan berakhir ketika masuk waktu magrib. Terkecuali pendapat Imam Abi Hanifah, bahwa masuknya waktu asar ialah ketika panjang bayangan suatu benda dua kali dari panjang bendanya.

Dalam perhitungan waktu asar panjang bayangan pada waktu zuhur yang merupakan panjang bayangan minimum perlu diperhitungkan, karena suatu saat mungkin panjang bayangan saat zuhur itu lebih panjang dari tinggi benda itu sendiri. Sehingga waktu asar adalah ketika panjang bayangan sebuah benda sama dengan panjang benda tersebut ditambah panjang bayangan waktu zuhur.

3. Masuk awal waktu magrib, dimulai saat matahari telah terbenam sebagaimana yang disebutkan dalam surah Hūd ayat 114 sebagai zulafam min al-lāl, yaitu permulaan malam yang ditandai dengan terbenamnya matahari. Nabi saw. juga pernah bersabda dalam riwayat Tirmizi yang artinya: "Dan awal waktu magrib ketika terbenam matahari, dan akhir waktunya ketika cahaya ufuk telah hilang...'17 Dengan kata lain waktu magrib adalah dimulai ketika terbenamnya semua piringan matahari di batas ufuk barat yakni tenggelamnya piringan atas matahari di ufuk barat. Waktu magrib berakhir ketika masuk waktu isya.

4. Masuk awal waktu isya, dimulai sejak hilangnya syafaq (mega) merah pada awan di langit barat. Ihwal waktu isya, Nabi saw. pernah bersabda dalam riwayat Muslim yang artinya: “...Dan waktu salat magrib selama belum

${ }^{16}$ Muslim bin Hajjaj bin Muslim al-Naisabūr, Șahih Muslim, (t.Cet; Beirut : Ihya al-Turaś, t.th.), Juz 1, hadis 427, h.612.

${ }^{17}$ Muhammad bin Isa al-Tirmiżi, Jāmi" al-Tirmiżi (t.cet.,t.t.p..al-maktabah syamilah.t.th), Beirut; Ihya al-turaś al-arabi, Juz 1, hadist 1696, h.283. 
hilang cahaya ufuk dan waktu salat isya adalah hingga setengah malam..."18 Menurut Imam Abi Hanifah, yaitu ketika hilangnya cahaya putih. Waktu isya berakhir sampai datangnya waktu fajar șādiq (masuk awal waktu subuh).

5. Masuk awal waktu subuh, dimulai sejak terbit fajar șādiq dan berakhir sampai terbitnya matahari, dalam surah al-Ṭūr ayat 49 disebutkan sejak ibdara al-nujūm, yaitu menghilangnya bintang-bintang dan berakhir seperti yang disebutkan dalam surah al-Qāf ayat 39 dengan sebutan thulü" $i$ al-syams, yaitu terbitnya matahari. Dalam hadis Nabi saw. pada riwayat Muslim berbunyi: “...Dan waktu salat subuh sejak terbitnya fajar, selama matahari belum terbit..."19 Waktu subuh berakhir ketika piringan atas matahari muncul di ufuk timur. Dalam istilah fikih memang istilah fajar sadiq dan fajar każib dikenal, namun kalangan astronomi hanya mengakui fajar șādiq karena tidak mungkin cahaya yang sudah nampak menghilang kembali (fajar kazib), artinya apabila cahaya sudah nampak berarti ia terus beredar menuju titik edar dan membentuk sudut yang lebih besar.

\section{Hukum Menggunakan Metode Ilmu Hisab/Falak dalam Penetapan Waktu Salat}

Melihat begitu besarnya faedah mempelajari ilmu falak, terlebih jika berkaitan dengan ibadah mahd $a h^{20}$ Dengan demikian, hukum mempelajarinya adalah wajib. Sebagaimana kaidah fikih yang berbunyi:

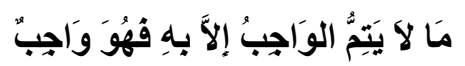

Artinya: "Sesuatu yang membuat segala bentuk kewajiban tidak menjadi sempurna kecuali denganya , maka sesuatu (hal) itu wajib hukumnya."

Awal waktu salat, arah kiblat, serta awal dan akhir puasa tidak dapat diketahui dengan pasti dan sempurna kecuali dengan ilmu falak, oleh sebab itulah hukum mempelajari ilmu falak menjadi wajib. Telah diketahui juga bahwa yang menjadi dasar dalam penetapan jadwal waktu salat secara syar'ī adalah al-alamah al-kauniyah (tanda-tanda alam) yang telah dijelaskan dalam Al-Qur'an dan sunah, sehingga ilmu falak sejatinya dimanfaatkan hanya sebagai sarana untuk mempermudah dalam penetapan jadwal waktu salat tersebut, namun bukan

${ }^{18} \mathrm{Abu}$ Ihsan al-Atsari, “Terjemah Bulughul Maram” (Cet.8; Solo: al-Tibyān, 2013) hadis 138 h. 75 . 138 h.75.

${ }^{19}$ Abu Ihsan al-Atsari, “Terjemah Bulughul Maram” (Cet.8; Solo: al-Tibyān, 2013) hadis

${ }^{20}$ Nur Hidayatullah Al-Banjary , Penemu Ilmu Falak, (Cet.1 ; Yogyakarta :Pusaka Ilmu, 2013), h..26-27. 
sebagai landasan utama. $^{21}$ TaqW̄m berdasarkan ilmu falak tersebut bisa saja dimanfaatkan oleh para muazin untuk mengetahui waktu salat sebagai alat bantu jika ditetapkan oleh orang-orang yang terkenal dan siqah (terpercaya), sehingga tidak pantas untuk ditolak secara mutlak. Dengan demikian, penggunaan perhitungan ilmu falak sebagai sarana dalam penetapan jadwal waktu salat adalah suatu keniscayaan, sekalipun dari hasil penerapannya masih tetap menuai kontroversi di kalangan ahli astronomi sendiri dan juga sebagian ulama. Namun, kekeliruan dalam beberapa versi jadwal salat tidak sepantasnya dijadikan alasan untuk menolak secara mutlak. ${ }^{22}$

\section{Pandangan Beberapa Ulama dan Pakar Ilmu Falak Terkait Jadwal Waktu Salat}

Perkara yang hangat diperdebatkan di kalangan para ahli ilmu falak dan juga para ulama adalah perkara awal masuknya salat subuh. Adapun waktu-waktu salat lain tampaknya tidak terlalu diperselisihkan sehingga lebih fokus membahas perbedaan dalam penetapan jadwal waktu salat subuh, sebab dianggap telah cukup untuk menggambarkan perbedaan dan penyebab munculnya beragam jadwal waktu salat. Terdapat beberapa pendirian para ulama dan ahli falak terkait jadwal waktu salat yang ditetapkan berdasarkan perhitungan ilmu astronomi. Ahmad al-Adwi ${ }^{23}$ dalam tulisannya "al-Qaul al-Qawān fi al-Salāti Hasba alTaquìm", meyebutkan tiga pandangan ulama dalam perkara ini khususnya waktu salat subuh versi Ummu al-Qura.

Pertama, anggapan yang mengatakan bahwa jadwal salat yang ada sudah benar, dan bahwa waktu salat fajar telah sesuai dengan fajar șādiq (fajar kedua). Kedua, anggapan bahwa jadwal salat lebih cepat 10 sampai 15 menit dari fajar șādiq. Ketiga, anggapan bahwa jadwal salat lebih cepat 20 hingga 25 menit, bahkan kadang mendahului fajar $k \bar{a} z ̇ i b$ (fajar pertama). ${ }^{24}$ Anggapan pertama membenarkan jadwal salat versi Ummu al-Qura yang menetapkan waktu fajar pada kriteria sudut $19^{\circ}$ hingga $19,30^{\circ}$ di bawah ufuk. Pendapat ini diperkuat oleh beberapa ulama besar Arab Saudi. Akan tetapi, syeikh Dr. Sa'ad bin Turki alKhaslan hafizahullāh beranggapan bahwa kriteria yang ditetapkan oleh Ummu al-Qura yakni $19^{\circ}$ adalah berdasarkan fajar $k \bar{a} z ̇ i b$, dan beberapa penelitian kontemporer telah membuktikan hal tersebut. ${ }^{25}$

${ }^{21}$ Sirajuddin Qasim, Makalah Menyikapi Polemik Jadwal Waktu Salat, 2017. h.8.

${ }^{22}$ Sirajuddin Qasim, Makalah Menyikapi Polemik Jadwal Waktu Salat, 2017. h.9.

${ }^{23}$ Dosen Fakultas Tehnik Di Universitas Tabuk Saudi Arabia.

${ }^{24}$ Disadur dari tulisan Ahmadi al-Adwi, al-qaulual-qawam fi al-salati hasba al-taqwim, 2009.http://www.ahlaldeeth.com/vb/showthread.php?t=183719, 20/08/2017.

${ }^{25}$ Disadur dari tulisan Ahmadi al-Adwi, al-qaulual-qawam fi al-salati hasba al-taqwim, 2009.http://www.ahlaldeeth.com/vb/showthread.php?t=183719, 20/08/2017. 
Asumsi di atas lalu dibantah oleh syekh Muhammad bin Muhammad alMukhtar al-Syinqiti hafizahullāh yang berpendapat bahwa untuk membedakan mana fajar șādiq dan fajar kāżib adalah perkara yang rumit bagi banyak orang. Jarak antara azan dan al-tabayyūn (jelasnya fajar) sangat dekat, hanya sekitar lamanya waktu minum seseorang. Adapun di tengah kota Madinah maka altabayyūn memang tidak bisa terlihat. Lalu beliau memperkuat pandangannya dengan mengutip hadis Aisyah ra. dalam Șah̄hain bahwa Nabi saw. pernah salat di waktu galas (akhir malam, awal fajar) dan kaum wanita belum bisa dikenali ketika bubar dari salat disebabkan kelamnya galas. Lebih lanjut beliau berkata, “...Dan jika Nabi saw azan fajar, lalu mengerjakan salat sunah fajar, setelah itu berbaring sesaat di atas sisi kanannya, lalu Bilal pun azan dan membangunkan beliau untuk salat dengan membaca antara 60 hingga 100 ayat dalam salat, lantas setelah selesai salat, ternyata kaum wanita belum bisa dibedakan dan dikenali, pantaskah kemudian kita menganggap bahwa jadwal yang ada hanyalah siasia?."26

Pendapat kedua berdasarkan pada hasil penelitian Abdul Malik 'Ali alKulaib $^{27}$ di Kuwait dan penanggalan Rabițah al-'Alam al-Islami yang menetapkan sudut fajar șā diq pada kriteria $17^{\circ}$ hingga $18^{\circ} .^{28}$ Tauqit inilah yang dikritisi oleh Syeikh Muhammad Nașiruddin al-Albani rahimahullāh, beliau berkata: "Rumahku terletak di bukit Hamlan diantara dataran-dataran tinggi Oman. Aku melihat langsung terbit dan terbenamnya matahari, mendengar azan magrib setelah terbenamnya matahari sekitar 10 menit padahal matahari tampak lebih dahulu terbenam bagi yang tinggal di lembah-lembah dan di tengah kota Oman, sebelum terlihat terbenam di tempat kami, sebaliknya, mereka justru azan fajar sebelum masuk waktu sekitar setengah jam - fainna lillāhi wa inna ilaihi rāji" un." 29

Adapun pendapat yang ketiga, maka berdasarkan pada penanggalan ISNA (Organisasi Persatuan Muslim Amerika Utara) dan hasil penelitian di Mesir melalui pemantauan langsung terbitnya fajar selama berkali-kali oleh banyak ahli

\footnotetext{
${ }^{26}$ Muhammad bin Muhammad al-Mukhtar al-Syinqiti, al-Tasykik fi waqti al-Fajr hasba Taqwim Ummulqura tanskripsi vidio (Qanat fawaid al-Mukhtar) no.37.

${ }^{27}$ Seorang peneliti dibidang astronomi di negara kuwait. Salah satu tulisan beliau yang terkenal "tashih wakti azan al fajr" diterbitkan oleh majalah al-azhar, kairo, 1997M (al-Adwi, 2009).

${ }^{28}$ Kriteria ini juga dianut oleh kemenag RI (18 derajat). Lihat : http;//sihat.kemenag.go.id/waktu-salat , 20/08/2017

${ }^{29}$ Muhammad Nasiruddin al-Albani, Silsilah al-Hadis al-Șahīhah, (t. Cet. ,t.t.p.:al-Maktabah al-Syamilah, t.th) Juz 5, hal 244.
} 
ilmu falak dan syariah, yang menetapkan terbitnya fajar pada kriteria posisi matahari pada sudut $14^{\circ}$ hingga $15^{\circ}$ di bawah ufuk..$^{30}$

Syeikh Muhammad bin Șālih al-Uṡaimīn rahimahullāh berkata, "terkait salat fajar, tauqit yang dikenal oleh masyarakat adalah keliru. Tauqit mendahului waktu sekitar 15 menit paling minimal, dan sebagian saudara-saudara kita keluar ke padang pasir dan mendapati perbedaan antara tauqit yang beredar di masyarakat dan terbitnya fajar sekitar sepertiga jam, perkara ini sangat berbahaya. Karenanya, bagi siapa yang ingin salat fajar tidak sepantasnya langsung mendirikan salat, tetapi selayaknya menangguhkan sekitar sepertiga jam hingga 25 menit agar ia yakin telah masuk waktu fajar."31

\section{Metode Penetapan Waktu Salat Menurut Dewan Syariah Wahdah Islamiyah}

\section{Hisab dan Rukyat}

Sebelum mengetahui metode penentuan awal waktu salat menurut Dewan Syariah Wahdah Islamiyah, maka ada baiknya kita mengenal secara umum metode hisab dan metode rukyat.

\section{Definisi Hisab}

Hisab secara harfiah adalah perhitungan. Dalam dunia Islam istilah hisab sering digunakan dalam ilmu falak atau astronomi untuk memperkirakan posisi matahari dan bulan terhadap bumi. Posisi matahari menjadi penting karena menjadi patokan umat Islam dalam menentukan masuknya waktu salat. Sementara posisi bulan diperkirakan untuk mengetahui terjadinya hilal sebagai penanda masuknya periode bulan baru dalam kalender hijriah. Hal ini penting terutama untuk menentukan awal Ramadhan saat muslim mulai berpuasa, awal Syawal (idul fitri) serta awal Zulhijjah. Dalam al-Qur'an surah Yunus ayat: 5 dikatakan bahwa Allah memang sengaja menjadikan matahari dan bulan sebagai alat menghitung tahun dan perhitungan lainnya. Juga dalam surah al-Rahman ayat: 5 disebutkan bahwa matahari dan bulan beredar menurut perhitungannya.

\footnotetext{
${ }^{30}$ Pendapat ini juga diperkuat oleh Dr. Agus Hasan Basori dalam makalah beliau " Persoalan waktu subuh ditinjau secara astronomi dan syar'i," 2011.

${ }^{31}$ Muhammad Șalih al-Uṡaimīn, Syarah Riyaḍ u al-Șālihin (t. cet., tt: al-maktabah syamilah, t. th), riyadh : daar al-wat an li al-nasyr. 1426H, juz 3, h.216.
} 
Oleh karena ibadah-ibadah dalam Islam terkait langsung dengan posisi bendabenda langit khususnya matahari dan bulan, maka sejak awal peradaban Islam menaruh perhatian besar terhadap astronomi. Perkembangan astronomi yang terjadi di dunia Islam, sebagian besar terjadi pada zaman keemasan Islam (abad ke-8 sampai abad ke-15), dan kebanyakan ditulis ke dalam bahasa Arab, perkembangan tersebut sebagian besar terjadi di Timur Tengah, Asia Tengah, AlAndalus, dan Afrika Utara, dan kemudian di Timur Jauh dan India, astronomi Islam kemudian memiliki pengaruh yang signifikan dalam astronomi Bizantium dan Eropa serta astronomi Tiongkok dan astronomi Mali. ${ }^{32}$

\section{Definisi Rukyat}

Rukyat menurut bahasa berasal dari kata ra'ā, yara, ra'yan, wa ru'yatan yang bermakna melihat, mengerti, menyangka, menduga dan mengira, serta memperhatikan. Dalam khazanah fikih, kata rukyat lazim disertai dengan kata hilal sehingga menjadi rukyatu al-hilal yang berarti melihat hilal (bulan baru). Rukyatu al-hilal ini berkaitan erat dengan masalah ibadah terutama ibadah puasa. Menurut Susiknan Azhari: “Rukyatu al-hilal adalah melihat atau mengamati hilal pada saat matahari terbenam menjelang awal bulan Qamariah dengan mata atau teleskop, dalam astronomi dikenal dengan observasi." 33 Kelebihan rukyat (observasion), pertama observasi merupakan metode ilmiyah yang akurat. Hal itu terbukti dengan berkembangnya ilmu falak pada zaman keemasan Islam. Kelemahan rukyat, pertama ketika matahari terbenam (sunset) di ufuk sebelah barat masih memancarkan sinar berupa mega merah (al-syafaq al-ahmar). Kedua, kendala cuaca. Di udara terdapat banyak partikel yang dapat menghambat pandangan mata seperti kabut, hujan, debu dan asap. Gangguan-gangguan ini mempunyai dampak terhadap pandangan pada hilal, termasuk mengurangi cahaya, ketiga, kualitas perukyat itu sendiri. ${ }^{34}$

\section{Metode Dewan Syariah Wahdah Islamiyah}

Kesimpulan hasil wawancara dengan Ketua Komisi Rukyat dan Falakiyah (KRF) Dewan Syariah Wahdah Islamiyah. Setelah mengkaji pembahasan tentang tanda-tanda awal masuknya waktu salat berdasarkan dalil-dalil syar" $\bar{\imath}$ baik dari al-Qur'an dan hadis dan kedudukan matahari melalui ilmu falak secara umum serta wawancara langsung dengan tokoh terkait secara khusus kepada Ketua

\footnotetext{
${ }^{32}$ https://id.wikipedia.org/wiki/Astronomi_di_dunia_Islam pada_Abad_Pertengahan akses pada tanggal 11/04/2020)

${ }^{33}$ Azhari, S. (2005). Ensiklopedi hisab rukyat. Pustaka Pelajar.

${ }^{34}$ Makalah Hisab rukyat, Kamakalandara.blogspot.co.id/.20 agustus 2017.
} 
komisi Rukyat dan Falakiyah Dewan Syariah Wahdah Islamiyah, maka dapat diketahui beberapa hal dalam menentukan awal waktu salat.

1. Dewan Syariah Wahdah Islamiyah dalam menetapkan jadwal waktu salat mengunakan dua metode di atas, metode rukyat sebagai metode utama dan metode hisab sebagai metede penunjang.

2. Dewan Syariah Wahdah Islamiyah sebagaimana ormas yang lain mengedepankan pengkajian dalil-dalil tentang awal waktu salat baik dari al-Qur'an maupun hadis.

3. Menjadikan landasan utama dalam memahami nash-nash syar'̄̄ melalui interpretasi para ulama berkompeten dan kredibel maupun ilmu falak.

4. Menjadikan standar penetapan waktu-waktu salat dengan melihat tandatanda kauniyah (alam) yang dijelaskan syariat al-Qur'an dan sunah melalui pengamatan langsung atau menggunakan alat bantu berupa teleskop atau alat astronomi lainnya.

5. Menjadikan ilmu hisab/falak sebagai alat bantu dalam perhitungan waktuwaktu salat melalui penjelasan ahli ilmu falak yang muslim dan siqah (terpercaya), namun bukan sebagai landasan utama.

6. Jika terjadi perbedaan antara tanda-tanda masuknya waktu shalat melalui pengamatan langsung yang akurat dan dapat dipertanggungjawabkan dengan hasil perhitungan ilmu falak, maka Dewan Syariah Wahdah Islamiyah lebih mengutamakan hasil dari pengamatan langsung (rukyat) sebab metode rukyat adalah metode yang qaț' (pasti menurut syariat), sementara ilmu hisab/falak adalah metode $z a n n \bar{\imath}$.

7. Jika terdapat dua jadwal waktu salat yang berbeda, maka yang lebih diutamakan adalah jadwal yang berdasarkan penetapannya pada tandatanda yang syar' $\bar{l}$ yang meyakinkan validitasnya serta melalui metode penetapan yang syar'ì pula.

8. Jadwal salat ditetapkan berdasarkan hasil pengamatan yang akurat terhadap tanda-tanda alam yang ditetapkan syariat.

9. Dewan Syariah Wahdah Islamiyah dalam menetapkan jadwal waktu salatnya, disamping berdasarkan tanda-tanda syar' $\bar{\imath}$ diatas, juga mempertimbangkan maslahat dan mudarat dari implikasi yang bisa saja ditimbulkan oleh jadwal tersebut di masyarakat, mengingat munculnya polemik jadwal waktu salat yang beragam dan beredar di kalangan masyarakat, dikhawatirkan justru akan lebih mempertajam masalah, dan bukan melahirkan sebuah solusi yang syar'’’.

10. Dalam proses penyusunan jadwal waktu salat, jadwal tersebut telah melewati rangkaian diskusi dan musyawarah di tengah para ahli fikih dan astronomi, baik yang memang telah berafiliasi dengan Ormas Wahdah 
Islamiyah atau pakar dari luar Wahdah Islamiyah yang siap memberikan masukan dan sumbangsinya seperti dari KEMENAG (dalam hal ini kepala LAPAN sekaligus ahli ilmu Falak kemenag RI. Prof. Dr. Thomas Djamaluddin) dan ormas-ormas lainnya.

11. Dewan Syariah Wahdah Islamiyah memandang tidak bolehnya menolak ilmu falak secara mutlak, alasannya adalah bahwa di dalam melakukan observasi di lapangan, banyak hal-hal yang dapat mempengaruhi hasil observasi tersebut, seperti perubahan cuaca, faktor kecemerlangan langit, tinggi rendahnya tempat observasi, pasang surutnya air laut, awan mendung serta curah hujan di lokasi observasi.

12. Dewan Syariah Wahdah Islamiyah senantiasa mengambil sikap pertengahan, termasuk dalam menetapkan awal waktu salat. Termasuk dalam penetapan waktu saat ini, contoh penetapan awal waktu salat subuh. Dewan Syariah Wahdah Islamiyah menetapkan waktu subuh $17,5^{\circ}$ posisi matahari di bawah ufuk dengan pertimbangan hasil observasi para ahli ilmu falak dalam menetapkan awal waktu terbitnya fajar sadiq paling tinggi diperoleh $20^{\circ}$ dan yang paling rendah $15^{\circ}$, sehingga Dewan Syariah berinisiatif mengambil pertengahan dari hasil keduanya.

13. Dewan syariah Wahdah Islamiyah dalam menetapkan waktu salat juga menetapkan waktu ihtiyat (kehati-hatian) antara dua hingga empat menit dari waktu yang telah ditetapkan.

14. Karena jadwal salat adalah perkara syar" $\bar{l}$, maka Dewan Syariah Wahdah Islamiyah senantiasa berhati-hati dalam menetapkannya. Memperhatikan banyak hal, selain dalil-dalil syar' $\bar{\imath}$, seperti maslahat dan mudarat.

15. Karena sarana observasi dan sumber daya manusia yang dimiliki Dewan Syariah Wahdah Islamiyah masih terbatas, maka dewan syariah untuk saat ini baru mampu menetapkan jadwal waktu salat setiap bulan, lantaran observasi dan perhitungan jadwal hanya bisa dilakukan pada setiap awal bulan Hijriah.

16. Sebelum jadwal salat disosialisasikan di tengah masyarakat umum, jadwal tersebut terlebih dahulu disebarkan di lingkungan interenal Wahdah Islamiyah. Tujuannya adalah untuk mengetahui kualitas dan implikasi jadwal itu berdasarkan respon dari para kadernya, kemudian selanjutnya disebarkan di tengah masyarakat jika telah dianggap layak.

\section{KESIMPULAN}

Permasalahan yang diangkat dalam penelitian ini yaitu; pertama, bagaimana fikih dan kedudukan matahari sebagai patokan utama menurut syariat dalam penentuan awal waktu salat; kedua, bagaimana hukum penggunaan ilmu 
hisab/falak dalam penentuan awal waktu salat; ketiga, bagaimana metode yang tepat dalam menentukan awal waktu salat sesuai syariat menurut Dewan Syariah Wahdah Islamiyah.

Penelitian ini bertujuan untuk mengetahui dan memahami metode yang tepat dalam menentukan waktu salat yang syar" $\bar{l}$ menurut Dewan Syariah Wahdah Islamiyah. Hasil penelitian menemukan bahwa; pertama, untuk mengetahui fikih dan kedudukan matahari sebagai patokan utama dalam penetapan awal waktu salat, harus dipahami berdasarkan dalil-dalil dalam al-Qur'an dan sunah melalui interpretasi para ulama yang diakui kredibilitas keilmuannya. Kedua, dalam menetapkan jadwal waktu salat, metode utama yang digunakan adalah metode rukyat dengan bantuan ilmu falak sebagai sarana dan alat bantu, namun bukan sebagai patokan dasar. Di samping itu, dalam proses penyusunan jadwal salat tersebut diharuskan melewati serangkaian diskusi dan musyawarah oleh para ahli fikih dan astronomi, baik yang telah berafiliasi dengan Wahdah Islamiyah ataupun pakar dari luar Wahdah Islamiyah yang siap memberikan masukan dan arahan.

\section{DAFTAR PUSTAKA}

Agus Hasan Basori. 2011. Persoalan Waktu Subuh Ditinjau Secara Astronomi dan Syar'i. Makalah.

Al-Banjary, N. H. (2013). Penemu Ilmu Falak: Pandangan Kitab Suci dan Peradaban Dunia. Yogyakarta: Pustaka Ilmu.

Al-Adwi, Ahmadi. 2009. Al-qaulual-Qawam Fi Al-Salati Hasba Al-Taqwim, 2009.http://www.ahlaldeeth.com/vb/showthread.php?t=183719.html. (20 Agustus 2017).

Al-Asqalani, A. H. I. H. (2013). Terjemah Bulughul Maram. Cet.8; Solo: alTibyān.

Azhari, S. (2005). Ensiklopedi hisab rukyat. Pustaka Pelajar.

Bashori, M. H. (2015). Pengantar Ilmu Falak: Pedoman Lengkap Tentang Teori dan Praktik Hisab, Arah Kiblat, Waktu Salat, Awal Bulan Qamariah \& Gerhana. Pustaka Al Kautsar.

Sugono, D. (2008). Kamus Besar Bahasa Indonesia Edisi Keempat. Pusat Bahasa DEPDIKNAS: Jakarta.

Departemen Agama Republik Indonesia. 2012. Al Kaffah, Al-Quran dan Terjemah, Jakarta: Sukses Publishing.

Ibnu Qudāmah Al-Maqdisī, al-Mughnī (t. Cet.; t.t.p.: al-Maktabah al-Syāmilah, t.th) [CD-ROM], al-Qāhirah: Maktabah al-Qāhirah. 1986, juz. I.

Muhammad bin Isa al-Tirmiżi, Jāmi"e al-Tirmiżi (t.cet.,t.t.p..al-maktabah 
syamilah.t.th), Beirut; Ihya al-turaś al-arabi, Juz 1.

Muhammad bin Muhammad al-Mukhtar al-Syinqiti, al-Tasykik fi waqti al-Fajr hasba Taqwim Ummulqura tanskripsi vidio (Qanat fawaid al-Mukhtar) no.37.

Muhammad Șalih al-Uśaimīn, Syarah Śalaśah Al-Ușul, (t. Cet ; t.t.p. :Dar al Kutub al-Ilmiyah, $1424 \mathrm{H}$ ). , Syarah Riyadu al-Ṣālihin (t. cet., tt: al-maktabah syamilah, t. th), riyadh : daar al-wat an li al-nasyr. 1426H, juz 3.

Muslim bin Hajjaj bin Muslim al-Naisabūr, Shahih Muslim, (t.Cet.; Beirut : Ihya al-Turaś, t.th) Juz 1.

Novira, N., \& Ahmad, A. (2019). Tinjauan Akidah Islam Terhadap Adat Mappalili di Balla Lompoa Kelurahan Baju Bodoa Kecamatan Maros Baru Kabupaten Maros Sulawesi Selatan. NUKHBATUL'ULUM: Jurnal Bidang Kajian Islam, 5(1), 15-25.

Pemula. 2014. Makalah Hisab rukyat. http://kamakalandara.blogspot.com/2014/10/makalah-hisab-rukyat.html. (20 Agustus 2017).

Sirajuddin Qasim. 2017. Menyikapi Polemik Jadwal Waktu Salat. Makalah.

Wikipedia. Astronomi di dunia Islam pada Abad Pertengahan. https://id.wikipedia.org/wiki/Astronomi_di_dunia_Islam_pada_Abad_Per tengahan. (11 April 2020).

Wikipedia. Wahdah Islamiyah. https://id.wikipedia.org/wiki/Wahdah_Islamiyah. (10 Februari 2020).

Yunta, A. H. D. (2019). Tinjauan Hukum Pelaksanaan Salat Id di Beberapa Masjid yang Berdekatan Dalam Satu Wilayah. NUKHBATUL'ULUM: Jurnal Bidang Kajian Islam, 5(1), 54-63.

http;//sihat.kemenag.go.id/waktu-salat. (20 Agustus 2017). 